DOI: $10.2478 / \mathrm{v} 10014-008-0011-8$

Agrovoc descriptors: tomatoes, lycopersicon esculentum, varieties, crop yield, crop performance, spacing, fertilizer application, phosphorus, phosphate fertilizers, nitrogen, nitrogen fertilizers, Ethiopia

Agris category codes: F04, F61, F62

COBISS Code 1.01

\title{
Response of tomato cultivars differing in growth habit to nitrogen and phosphorus fertilizers and spacing on vertisol in Ethiopia
}

\author{
Tesfaye BALEMI ${ }^{1}$
}

Received: June 29, 2007; accepted: March 21, 2008.

Prispelo 29. junija 2007; sprejeto 21. marca 2008.

\begin{abstract}
A field experiment was conducted on vertisol at Ambo University College (Ethiopia) during $2003 / 2004$ and 2004/2005 cropping seasons to investigate the response of tomato cultivars varying in growth habit to rates of Nitrogen $(\mathrm{N})$ and Phosphorus $(\mathrm{P})$ fertilizers and plant spacing. The treatment consisted of factorial combination of two cultivars (Margelobe and Melka shola),

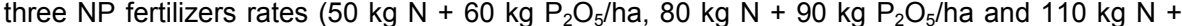
$\left.120 \mathrm{~kg} \mathrm{P} \mathrm{P}_{5} / \mathrm{ha}\right)$ and three spacing $(100 \mathrm{~cm} \times 30 \mathrm{~cm}, 80 \mathrm{~cm} \times 30 \mathrm{~cm}$ and $60 \mathrm{~cm} \times 45 \mathrm{~cm})$ arranged in a Randomized Complete Block Design. Results revealed that fertilizer rates and spacing significantly affected the total and marketable fruit yields as well as \% marketable fruit yield. Similarly, plant vigor (plant height), number of fruits per cluster and 10 fruit weight were significantly influenced by all of the main factors. Besides the main factors effect, fertilizer rate*spacing and cultivar*spacing interaction effects were also observed on $\%$ marketable fruit yield and 10 fruit weight, respectively. The results of 2003/2004 cropping season showed that the application of $110 \mathrm{~kg} \mathrm{~N}+120 \mathrm{~kg} \mathrm{P}_{2} \mathrm{O}_{5} / \mathrm{ha}$ or $80 \mathrm{~kg} \mathrm{~N}+90 \mathrm{~kg} \mathrm{P}_{2} \mathrm{O}_{5} /$ ha resulted in significantly higher total as well as marketable fruit yield of the tomato cultivars. Result of 2004/2005 cropping season, however, demonstrated that only the application the highest fertilizer rate (110 $\mathrm{kg} \mathrm{N}+120 \mathrm{~kg} \mathrm{P}_{2} \mathrm{O}_{5} / \mathrm{ha}$ ) resulted in superior fruit yields whilst the other two rates did not significantly differ from each other in affecting fruit yields. Results of both cropping seasons confirmed significantly higher \% marketable fruit yield due to the application of either $110 \mathrm{~kg} \mathrm{~N}+$ $120 \mathrm{~kg} \mathrm{P} \mathrm{O}_{5} / \mathrm{ha}$ or $80 \mathrm{~kg} \mathrm{~N}+90 \mathrm{~kg} \mathrm{P} \mathrm{O}_{5} /$ ha. Closer spacing of $80 \mathrm{~cm} \times 30 \mathrm{~cm}$ and $60 \mathrm{~cm} \times 45$ $\mathrm{cm}$ gave higher total as well as marketable fruit yield than the wider spacing of $100 \mathrm{~cm} \times 30 \mathrm{~cm}$.
\end{abstract}

Key words: fertilizer rate, marketable fruit yield, tomato cultivars, total fruit yield, spacing

\footnotetext{
1 Department of Plant Sciences, Ambo University College, P.O Box 19, Ethiopia, E-mail: tesfayeb2005@yahoo.co.uk
} 
IZVLEČEK

\section{VPLIV GNOJENJA Z DUŠIKOM IN FOSFORJEM NA RASTLINE KULTIVARJEV PARADIŽNIKA Z RAZLIČNO RASTJO NA VERTISOLU V ETIOPIJI}

Na Ambo University College v Etiopiji je bil v letih 2003/2004 in 2004/2005 izveden poljski poskus z dvema kultivarjema paradižnika (determinantnim in nedeterminantnim) da bi raziskali vpliv gnojenja $z$ dušikom $(\mathrm{N})$ in fosforjem $(\mathrm{P})$ ter razdalje med rastlinami na paradižnik. Izveden je bil faktorski poskus $z$ dvema kultivarjema (Margelobe in Melka shola), tremi odmerki gnojil NP $\left(50 \mathrm{~kg} \mathrm{~N}+60 \mathrm{~kg} \mathrm{P} \mathrm{O}_{5} / \mathrm{ha}, 80 \mathrm{~kg} \mathrm{~N}+90 \mathrm{~kg} \mathrm{P} \mathrm{O}_{5} / \mathrm{ha}\right.$ in $\left.110 \mathrm{~kg} \mathrm{~N}+120 \mathrm{~kg} \mathrm{P}_{2} \mathrm{O}_{5} / \mathrm{ha}\right)$ in tremi razdaljami med rastlinami $(100 \mathrm{~cm} \times 30 \mathrm{~cm}, 80 \mathrm{~cm} \times 30 \mathrm{~cm}$ in $60 \mathrm{~cm} \times 45 \mathrm{~cm})$ v naključnem bloku. Rezultati so pokazali, da so stopnje gnojenja in gostota rastlin značilno vplivali na celoten in tržen pridelek raslin, kot tudi na odstotek uporabnega pridelka. Podobno so bile višine rastlin, teža in število plodov v značilni povezavi z vsemi glavnimi faktorji. Poleg glavnih vplivom so vplivale tudi interakcije gnojenje* ${ }^{*}$ gostota in kultivar*razdalje tako na \% tržnega pridelka plodov kot na težo 10 plodov. Rezultati v sezoni 2003/2004 so pokazali da je uporaba $110 \mathrm{~kg} \mathrm{~N}+120$ $\mathrm{kg} \mathrm{P}_{2} \mathrm{O}_{5} /$ ha ali $80 \mathrm{~kg} \mathrm{~N}+90 \mathrm{~kg} \mathrm{P}_{2} \mathrm{O}_{5} /$ ha omogočila značilno višje celokupne in tržne pridelke paradižnikov pri obeh kultivarjih. Toda v sezoni 2004/2005 je samo najvišji odmerek gnojil (110 $\mathrm{kg} \mathrm{N}+120 \mathrm{~kg} \mathrm{P}_{2} \mathrm{O}_{5} /$ ha ) dal višje pridelke. Rezultati obeh sezon skupaj so potrdili višji \% tržnega pridelka pri uporabi $110 \mathrm{~kg} \mathrm{~N}+120 \mathrm{~kg} \mathrm{P} \mathrm{O}_{5} / \mathrm{ha}$ ali $80 \mathrm{~kg} \mathrm{~N}+90 \mathrm{~kg} \mathrm{P} \mathrm{P}_{2} \mathrm{O}_{5} /$ ha. Gostejša saditev $(80 \mathrm{~cm} \times 30 \mathrm{~cm}$ oziroma $60 \mathrm{~cm} \times 45 \mathrm{~cm})$ je dala višje pridelke kot redkejša saditev (100 $\mathrm{cm} \times 30 \mathrm{~cm})$.

Ključne besede: celoten pridelek, gostota saditve, kultivarji paradižnika, odmerki gnojil, tržni pridelek

\section{INTRODUCTION}

Tomato (Lycopersicon esculentum L.) is the most widely grown vegetable in the world being recognized as a reach source of vitamins and minerals. It is also among the most important vegetable crops in Ethiopia. The total production of this crop in the country has shown a marked increase (Lemma et al., 1992) since it became the most profitable crop providing a higher income to small scale farmers compared to other vegetable crops. However, tomato production is highly constrained by several factors especially in developing nations like Ethiopia. The national average of tomato fruit yield in Ethiopia is often low (125 q/ha) compared even to the neighboring African countries like Kenya (164 q/ha) (FAO Production Year Book, 2004). Current productivity under farmers' condition is $90 \mathrm{q} / \mathrm{ha}$, whereas yield up to 400 q/ha can be recorded on research plots (personal communication).

In Ethiopia, farmers get lower yield mainly due to diseases and pests as well as due to sub-optimal fertilization. Mehla et al., (2000) and Pandey et al., (1996) reported that fruit yield in tomato is highly influenced by the NP fertilizers rates applied. Similarly, Sherma et al., (1999) also reported average fruit weight of tomato to have been influenced by the amount of NP fertilizers rates applied. Thus, tomato plant should receive optimum amount of NP fertilizers to produce higher fruit yields. According to (http://www.avrdc.org, 2007) the total nitrogen $\left(\mathrm{kg} \mathrm{ha}^{-1}\right)$ required to achieve a target fruit yield is estimated by multiplying the target yield in tons per hectare by 2.4. Similarly, $\mathrm{P}_{2} \mathrm{O}_{5}$ requirement per hectare can be estimated by multiplying $\mathrm{N}$ requirement by 0.35 (http://www.avrdc.org, 2007). 
Improper plant spacing is also among the notable reasons of low productivity of this crop. Lemma et al., (1992) reported that plant spacing greatly influenced fruit yield in both fresh market and processing tomatoes. Likewise, Godfrey-Sam-Aggrey et al., (1985) and Mehla et al., (2000) also reported yield parameters in tomato to have been affected by spacing.

In Ethiopia, so far plant spacing and fertilizer rates were determined for tomatoes only at Melkasa research center which can not agro-ecologically represent the other tomato growing regions of the country and especially no such study was done in tomatoes under vertisol condition and the whole of such previous agronomic studies were confined only to sandy loam soils of the rift valley regions of the country. Although the tomato growers in the rift valley regions can directly use the recommendation from this research center, the same recommendation however, can not apply for the other tomato growing regions with completely different agroecology. In tropics in general, the common fertilizer application rates according to literature are 60-120 kg N, and 60-140 $\mathrm{kg}_{2} \mathrm{O}_{5}$ and 60-120 kg $\mathrm{K}_{2} \mathrm{O}$ per hectare (http://www.avrdc.org, 2007). However, this would also be too general to use for specific regions. Since spacing requirement of tomato depends on soil type and its inherent fertility (Lemma et al., 1992) and the type of cultivars (Mehla et al., 2000), the use of blanket recommendation would be inappropriate and it would be indispensable to identify appropriate recommendation for specific soil types and cultivars grown in the region. Thus, the present investigation was proposed with an objective to determine an optimum fertilizer rate and plant spacing for tomato cultivars with contrasting growth habits grown in vertisol dominated region of the central Ethiopia.

\section{MATERIALS AND METHODS}

The experiment was conducted in the field for two years (2003/2004 and 2004/2005 cropping seasons) on vertisol in Ethiopia at Ambo University College experimental station during offseason with irrigation. Two commonly grown tomato cultivars with contrasting growth habit (Margelobe: an indeterminate cultivar and Melka shola a determinate type) were used for the study. The treatments consisted of factorial combination of two above mentioned cultivars, three spacings $(100 \mathrm{~cm} \times 30 \mathrm{~cm}, 80 \mathrm{~cm} \times 30 \mathrm{~cm}$ and $60 \mathrm{~cm} \times 45 \mathrm{~cm})$ where the larger spacing always stands for inter-row spacing and the other for intra-row spacing) and three fertilizer rates (50 kg

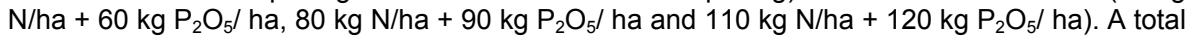
of 18 treatments were laid out in Randomized Complete Block Design (RCBD) with three replications. The plot size used was $1.8 \mathrm{~m} \times 4 \mathrm{~m}$ (Plot area $=7.2 \mathrm{~m}^{2}$ ) in both years of experimentation. The nitrogen fertilizer $(N)$ was applied as urea whereas phosphorus $(P)$ was applied in the form of Diammonium Phosphate (DAP) both of which are commonly used forms of chemical fertilizers by the small-scale farmers and commercial growers in the country. The whole amount of phosphate fertilizer was applied at transplanting whereas nitrogen was given at two equal splits (half at transplanting and the rest half 30 days after transplanting) as basal application. No any other nutrient was applied since especially Potassium is not limiting in most Ethiopian soils. Data was recorded on plant height (plant vigor) at 60 days after transplanting, number of fruits per cluster and 10 fruit weight only during the first cropping season experiment. However, data on total and marketable fruit yields were recorded during both cropping season experiments. Data for plant height and number of fruits per cluster were determined for 5 randomly selected sample plants for every treatment in each block (i.e. values of each treatment in every block are averages of 5 plants). To see the effect of each factor (cultivars, spacing and fertilizer rate) on the measured parameters, the data were analyzed by analysis of variance-ANOVA and in all cases means were compared at $\alpha=0.05$ probability level according to Tukey test using SAS statistical software. 


\section{RESULTS AND DISCUSSION}

\section{Effect of main factors on total fruit yield}

\section{Fertilizer rate}

Generally, higher total fruit yield was obtained during the first year (2003/2004 cropping season) experiment than during the second year (2004/2005 cropping season) experiment. This was mainly because the fruits were harvested over an extended period of time during the first year experiment. The analysis of variance (ANOVA) showed that there was significant main effect of fertilizer rates $(\mathrm{P}<0.01)$ on the total fruit yield of the tomato cultivars during both cropping seasons (Tables 1 and 2). During the first year experiment, significantly higher total fruit yield (80.5 kg plot ${ }^{-1}$ ) was obtained with the application of $110 \mathrm{~kg} \mathrm{~N}+120 \mathrm{~kg} \mathrm{P}_{2} \mathrm{O}_{5}$ per hectare as compared to the application of $50 \mathrm{~kg} \mathrm{~N}+60 \mathrm{~kg} \mathrm{P}_{2} \mathrm{O}_{5}$ per hectare which gave a total fruit yield of only $66 \mathrm{~kg} \mathrm{plot}^{-1}$ (Figure 1). During the same year, the application of $80 \mathrm{~kg} \mathrm{~N}+90 \mathrm{~kg} \mathrm{P}_{2} \mathrm{O}_{5}$ per hectare resulted in a total fruit yield of $73 \mathrm{~kg} \mathrm{plot}^{-1}$ which was on par with that obtained with the application of the highest fertilizer rate (110 kg N $+120 \mathrm{~kg} \mathrm{P}_{2} \mathrm{O}_{5}$ per hectare). During the second year experiment (2004/2005 cropping season), significantly higher total fruit yield (46.6 $\left.\mathrm{kg} \mathrm{plot}^{-1}\right)$ was obtained with the application of $110 \mathrm{~kg} \mathrm{~N}+120 \mathrm{~kg} \mathrm{P}_{2} \mathrm{O}_{5}$ per hectare as compared to the application of both $80 \mathrm{~kg} \mathrm{~N}+90 \mathrm{~kg} \mathrm{P}_{2} \mathrm{O}_{5}$ and $50 \mathrm{~kg} \mathrm{~N}+60 \mathrm{~kg} \mathrm{P}_{2} \mathrm{O}_{5}$ per hectare which gave a total fruit yield of 38.3 and $35.7 \mathrm{~kg} \mathrm{plot}^{-1}$, respectively (Figure 1). The application of $80 \mathrm{~kg} \mathrm{~N}+90 \mathrm{~kg}_{2} \mathrm{O}_{5}$ per hectare did not significantly differ from the application of $50 \mathrm{~kg} \mathrm{~N}+60 \mathrm{~kg} \mathrm{P}_{2} \mathrm{O}_{5}$ per hectare in affecting the total fruit yields of the tomato cultivars during both cropping seasons. Higher total fruit yield in tomato at higher NP rate was reported by Rashid (1993), Pandey et al., (1996) and Mehla et al., (2000), which is in agreement with the present finding.

\section{Spacing}

Total fruit yield was also significantly affected by the spacing $(\mathrm{P}<0.05)$ during both years experiments (Tables 1 and 2). During the first year experiment, the mean total fruit yield of the tomato cultivars ranged between $78.6 \mathrm{~kg} \mathrm{plot}^{-1}$ and $67.6 \mathrm{~kg} \mathrm{plot}^{-1}$ due to spacing effect which was significantly different $(\mathrm{P}<0.05)$ (Figure 4). A plant spacing of $80 \mathrm{~cm}$ x $30 \mathrm{~cm}$ resulted in the highest mean total fruit yield $\left(78.6 \mathrm{~kg} \mathrm{plot}^{-}\right.$ ${ }^{1}$ ) whereas spacing of $100 \mathrm{~cm} \times 30 \mathrm{~cm}$ gave the lowest mean total fruit yield (67.6 $\mathrm{kg} \mathrm{plot}^{-1}$ ). Likewise, similar effect of spacing on the total fruit yield was observed during the second year experiment. A closer spacing of $80 \mathrm{~cm}$ x $30 \mathrm{~cm}$ resulted in significantly higher total fruit yield $\left(44.0 \mathrm{~kg} \mathrm{plot}^{-1}\right)$ as compared to a wider spacing of $100 \mathrm{~cm} \times 30 \mathrm{~cm}$ which gave a total fruit yield of $35.80 \mathrm{~kg} \mathrm{plot}^{-1}$. However, a spacing of $60 \mathrm{~cm} \times 45 \mathrm{~cm}$ gave a total yield which was on par with the other spacing treatments during both cropping seasons. The present finding draws support from earlier reports of Reeve and Schmidth (1952), Zahara (1970), Gupta and Shukla (1977), Ali (1995), Teerapolvichitra (1983), Hamid (1985), Nassar (1986) and Mohamed and Ali (1986) who similarly reported the highest total fruit yield of tomato at closer spacing than at wider spacing. The highest total fruit yield of the tomato cultivars at closer spacing could be due to the higher plant population per 
plot at closer spacing than at wider spacing as reported by Jia (1992). Moreover, the closer spacing might have enabled maximized use of the applied nutrients better than the wider spacing as has been suggested by Mbinga (1983).

\section{Cultivars}

Cultivars did not significantly differ in total fruit yield during both year experiments (Tables 1 and 2).

\section{Interaction effects}

No interaction effects of all factors on total fruit yield were observed during both year experiments in the present finding (Tables 1 and 2). However, Mehla et al. (2000) reported significant interaction effects of cultivar*spacing and fertilizer*spacing for total fruit yield in tomato.

\section{Effect of main factors on marketable and \% marketable fruit yield}

\section{Fertilizer rate}

Marketability of the produce is of paramount importance to tomato growers since they primarily produce for market. In the present study, undersized fruits, sunscald fruits and fruits attacked by insects were regarded as unmarketable fruits. Marketable and \% marketable fruit yield were significantly affected by fertilizer rates $(\mathrm{P}<0.001)$ during both cropping seasons (Tables 1 and 2). During both year experiments, the trend of fertilizer effect on total fruit yield was also similar to its effect on marketable fruit yield. During the first year experiment (2003/2004 cropping season), application of the highest fertilizer rate $(110 \mathrm{~kg} \mathrm{~N}+120 \mathrm{~kg}$ $\mathrm{P}_{2} \mathrm{O}_{5} / \mathrm{ha}$ ) gave significantly higher mean marketable fruit yield (76.1 $\mathrm{kg} \mathrm{plot}^{-1}$ ) than the lowest fertilizer rate (50 kg N $+60 \mathrm{~kg} \mathrm{P}_{2} \mathrm{O}_{5} / \mathrm{ha}$ ) which gave mean marketable fruit yield of only $59.1 \mathrm{~kg} \mathrm{plot}^{-1}$ (Figure 2). During 2004/2005 cropping season, the same fertilizer rate $\left(110 \mathrm{~kg} \mathrm{~N}+120 \mathrm{~kg} \mathrm{P}_{2} \mathrm{O}_{5} / \mathrm{ha}\right.$ ) exerted a significant influence in boosting marketable fruit yield as compared to the other rates. The application of $110 \mathrm{~kg} \mathrm{~N}+120 \mathrm{~kg} \mathrm{P}_{2} \mathrm{O}_{5}$ per hectare resulted in mean marketable fruit yield of 41.4 $\mathrm{kg}_{\text {plot }}{ }^{-1}$ which was significantly higher as compared to marketable fruit yield of $33.0 \mathrm{~kg} \mathrm{plot}^{-1}$ and $27.2 \mathrm{~kg}$ plot $^{-1}$, which were obtained with the application of $80 \mathrm{~kg}$ $\mathrm{N}+90 \mathrm{~kg} \mathrm{P}_{2} \mathrm{O}_{5}$ and $50 \mathrm{~kg} \mathrm{~N}+60 \mathrm{~kg} \mathrm{P}_{2} \mathrm{O}_{5}$ per hectare, respectively. Application of

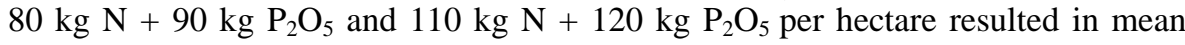
marketable fruit yields which were on par during the first year but significantly different during the second year experiment.

For all levels of fertilizer, \% marketable fruit yield of the tomato cultivars significantly differed during 2003/2004 cropping season (Figure 3). Application of $110 \mathrm{~kg} \mathrm{~N}+120 \mathrm{~kg} \mathrm{P}_{2} \mathrm{O}_{5}$ per hectare resulted in significantly higher mean \%

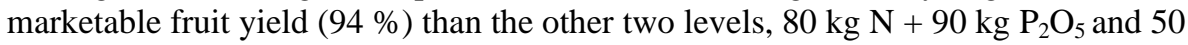
$\mathrm{kg} \mathrm{N}+60 \mathrm{~kg} \mathrm{P}_{2} \mathrm{O}_{5}$ per hectare, which gave a mean \% marketable fruit yield of 91.9 $\%$ and $88.8 \%$, respectively. On the other hand, during 2004/2005 cropping season, $\%$ marketable fruit yield which was obtained with the application of $110 \mathrm{~kg} \mathrm{~N}+120$ 
$\mathrm{kg} \mathrm{P}_{2} \mathrm{O}_{5} /$ ha $(87.7 \%$ ) did not significantly differ from that obtained with the application of $80 \mathrm{~kg} \mathrm{~N}+90 \mathrm{~kg} \mathrm{P}_{2} \mathrm{O}_{5} / \mathrm{ha}(85.5 \%)$, but both of these fertilizer rates gave significantly higher \% marketable fruit yield when compared to the application of the lowest rate (50 kg N $+60 \mathrm{~kg} \mathrm{P}_{2} \mathrm{O}_{5}$ per hectare), which gave $81.6 \%$ mean marketable fruit yield. The higher marketable fruit yield under higher NP rate might have been achieved probably because the higher NP rate might have improved fruit size thereby contributing to greater marketable fruit yield per plot. However, so far no report was found on the influence of NP fertilizers on marketable and \% marketable fruit yields practically for tomato to substantiate the present finding.

\section{Spacing}

Similar to fertilizer rate, spacing also significantly influenced marketable fruit yield and \% marketable fruit yield $(\mathrm{P}<0.001)$ (Tables 1 and 2$)$. During both cropping seasons, a spacing of $80 \mathrm{~cm} \mathrm{x} 30 \mathrm{~cm}$ and $60 \mathrm{~cm}$ x $45 \mathrm{~cm}$ resulted in significantly higher mean marketable fruit yield as compared to $100 \mathrm{~cm} \mathrm{x} 30 \mathrm{~cm}$ (Figure 5). The tomato cultivars also produced significantly different \% marketable fruit yields at all spacing and a spacing of $80 \mathrm{~cm} \mathrm{x} 30 \mathrm{~cm}$ gave the highest mean \% marketable fruit yield followed by a spacing of $60 \mathrm{~cm} \mathrm{x} 45 \mathrm{~cm}$ whereas a wider spacing of $100 \mathrm{~cm} \mathrm{x}$ $30 \mathrm{~cm}$ gave the lowest mean \% marketable fruit yield during both seasons (Figure 6). Teerapolvichitra (1983) also reported the highest marketable fruit yield at closer spacing than at wider spacing, which supports the present finding. However, Godfrey-Sam-Aggrey et al., (1985) and Mehla et al., (2000) reported increased marketable fruit yield at wider spacing which contradicts with the present finding. The higher marketable fruit yield at closer spacing in the current investigation could be due to reduced number of sunscald fruits as has been reported by Mohamed and Ali (1986).

\section{Cultivars:}

There was no significant effect of cultivars on marketable fruit yield during both cropping seasons ( $\mathrm{P}>0.05$ ) (Tables 1 and 2). However, significant effect of cultivar on \% marketable fruit yield was observed during 2003/2004 cropping season (Table 1) with Melka shola producing significantly higher mean \% marketable fruit yield (mean data not shown). On the other hand, Warner (2003) have observed significant effect of cultivar on marketable fruit yield of tomato during his first year experiment but this was not repeated in his second and third year experiments. The significant $\%$ marketable fruit yield in the present investigation could be due to the greater canopy and growth habit of this determinate cultivar (Melka shola) to cover the fruits from sun scalding thereby contributing to reduced unmarketable fruit yield record of this cultivar.

\section{Interaction effect:}

During 2003/2004 cropping season, significant fertilizer*spacing interaction effect was observed on \% marketable fruit yield (Table 1). According to the result, at

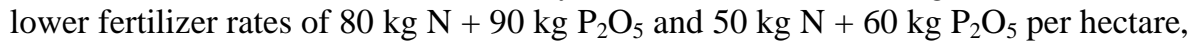
plant spacing of $80 \mathrm{~cm}$ x $30 \mathrm{~cm}$ and $60 \mathrm{~cm}$ x $45 \mathrm{~cm}$ produced significantly higher \% marketable fruit yield as compared to wider spacing of $100 \mathrm{~cm}$ x $30 \mathrm{~cm}$ (Table 5). 
On the other hand, at the highest fertilizer rate of $110 \mathrm{~kg} \mathrm{~N}+120 \mathrm{~kg}_{2} \mathrm{O}_{5} / \mathrm{ha}$, the mean \% marketable fruit yield significantly differed for all spacing and the highest and lowest mean \% marketable fruit yield was produced at a spacing of $80 \mathrm{~cm}$ x 30 $\mathrm{cm}$ and $100 \mathrm{~cm} \mathrm{x} 30 \mathrm{~cm}$, respectively.

\section{Effect of main factors on plant height (plant vigour)}

All the main factors had highly significant effect on plant height 60 days after transplanting $(\mathrm{P}<0.001)$. However, there was no interaction effect for any of the main factor (Table 3). An indeterminate cultivar Margelobe had significantly higher mean plant height $(72.8 \mathrm{~cm})$ than a determinate cultivar, Melka shola $(64.9 \mathrm{~cm})$ (Table 4). The significant difference in plant height between the two cultivars could be due to their distinct growth habit. Plant height was also significantly affected by the rates of fertilizer applied $(\mathrm{P}<0.001)$. All the three fertilizer rates differed significantly from each other in influencing plant height with $110 \mathrm{~kg} \mathrm{~N}+120 \mathrm{~kg}$ $\mathrm{P}_{2} \mathrm{O}_{5}$ per hectare resulting in the highest mean plant height $(81.7 \mathrm{~cm})$ followed by 80

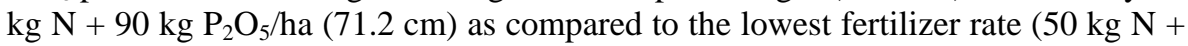
$60 \mathrm{~kg} \mathrm{P}_{2} \mathrm{O}_{5}$ per hectare) which resulted in mean plant height of only (53.8 cm) which was significantly lower compared to the above two (Table 4). Plant height was also significantly influenced by spacing $(\mathrm{P}<0.001)$. Closer spacing of $60 \mathrm{~cm} \mathrm{x} 45 \mathrm{~cm}$ and $80 \mathrm{~cm} \times 30 \mathrm{~cm}$ resulted in significantly higher plant height compared to a wider spacing of $100 \mathrm{~cm}$ x $30 \mathrm{~cm}$ (Table 4). Mbinga (1995) and Gupta and Shukla (1977) also reported increased plant height in tomato at closer spacing than at wider spacing which is in line with the present result.

\section{Effect of main factors on number of fruits per cluster}

The two cultivars differed significantly in total fruit number per cluster $(\mathrm{P}<0.001)$, Melka shola on average producing more number of fruits per cluster (5.9 fruits/cluster) and Margelobe producing less number of fruits per cluster (4.5 fruits per cluster) (Table 4). Moreover, fertilizer rate also significantly affected number of fruits per cluster $(\mathrm{P}<0.001)$ and the tomato cultivars showed significant variation in this parameter for all levels of fertilizers applied. The highest number of fruits per cluster (5.97) was obtained with the application of $110 \mathrm{~kg} \mathrm{~N}+120 \mathrm{~kg} \mathrm{P}_{2} \mathrm{O}_{5} / \mathrm{ha}$ whereas the lowest rates of fertilizers resulted in the lowest number of fruits per cluster (4.39) (Table 4). This, however, contradicts with the report of Rashid (1993) who did not observe significant effect of fertilizer rate on number of fruits per cluster at higher NP rate in his study. The highest number of fruits per cluster at high NP rate in this study could be due to the positive effect, especially of $\mathrm{P}$, on flower formation and subsequent fruit formation. Likewise, fruit number per cluster was also significantly influenced by spacing, the wider spacing of $100 \mathrm{~cm}$ x $30 \mathrm{~cm}$ resulting in significantly more number of fruits per cluster as compared to a closer spacing of $60 \mathrm{~cm} \mathrm{x} 45 \mathrm{~cm}$ (Table 4). A spacing of $80 \mathrm{~cm} \mathrm{x} 30 \mathrm{~cm}$, however, did not significantly differ from the other spacing in influencing fruit number per cluster. Nevertheless, no clear trend of effect of spacing on number of fruits per cluster could be illustrated according to the result of the present investigation. 


\section{Effect of main factors on average weight of 10 fruits}

Ten fruit weight was significantly affected by all main factors (cultivars, fertilizer rate and spacing) $(\mathrm{P}<0.001$ in all cases) (Table 3$)$. Marglobe, gave significantly higher mean value of ten fruit weight $(1.54 \mathrm{~kg})$ compared to Melka shola $(0.85 \mathrm{~kg})$ and this was purely due to the genetic difference in fruit size of the two cultivars. Jia (1992) also similarly observed significant difference in average fruit weight between tomato cultivars differing in growth habit, the indeterminate cultivar showing higher average fruit weight than the determinate cultivar, which was similar to the present observation. With regard to the effect of fertilizer rate, the application of $110 \mathrm{~kg} \mathrm{~N}+$ $120 \mathrm{~kg} \mathrm{P}_{2} \mathrm{O}_{5} / \mathrm{ha}$ and $80 \mathrm{~kg} \mathrm{~N}+90 \mathrm{~kg} \mathrm{P}_{2} \mathrm{O}_{5} /$ ha resulted in significantly higher mean value of ten fruit weight (1.31 kg and $1.23 \mathrm{~kg}$, respectively) of the tomato cultivars as compared to the application of the lowest rate of fertilizer $(50 \mathrm{~kg} \mathrm{~N}+60 \mathrm{~kg}$ $\mathrm{P}_{2} \mathrm{O}_{5} / \mathrm{ha}$ ) which gave mean ten fruit weight value of $1.05 \mathrm{~kg}$ (Table 4). This result is also in line with earlier report of Sharma et al., (1999) who recorded greater average tomato fruit weight with the application of higher NP fertilizers rates. Contrary to the present result, Rashid (1993) did not observe any significant influence of fertilizer rates on this parameter in his study. The highest mean value of ten fruit weight $(1.41 \mathrm{~kg})$ of the tomato cultivars was obtained at a wider spacing of $100 \mathrm{~cm}$ x $30 \mathrm{~cm}$ whereas the lowest value $(1.02 \mathrm{~kg})$ was recorded at a spacing of $60 \mathrm{~cm}$ x 45 $\mathrm{cm}$, which were significantly different (Table 4). This result was in line with the earlier report of Ali (1997) who found higher average fruit weight at wider spacing as compared to closer spacing. Jia (1992), however, did not observe any significant influence of spacing on average fruit weight of both determinate and indeterminate types of tomatoes in his study.

Additionally, cultivar*spacing interaction effect was also detected as significant for the parameter under discussion $(\mathrm{P}<0.05)$ (Table 3). For Margelobe the mean value of ten fruit weight significantly differed at all plant spacing investigated (Table 6). For this cultivar significantly higher mean value of ten fruit weight was obtained at a plant spacing of $100 \mathrm{~cm}$ x $30 \mathrm{~cm}(1.8 \mathrm{~kg})$ while the lowest mean value of ten fruit weight (1.3 kg) was obtained at a plant spacing of $60 \mathrm{~cm} \mathrm{x} 45 \mathrm{~cm}$ (Table 6). On the other hand, for Melka shola except for a spacing of $100 \mathrm{~cm}$ x $30 \mathrm{~cm}$, which produced significantly higher ten fruit weight $(1.03 \mathrm{~kg})$, the other two spacing did not result in significantly different mean value of ten fruit weight $(0.77 \mathrm{~kg}$ and 0.76 $\mathrm{kg}$, respectively).

\section{Acknowledgment}

The Author acknowledges Mrs. Etagegn Teshome for her technical assistance right from planting up to field data collection. The author also acknowledges Mr. Bekele Taddesse, and Mr. Ashenafi Chaka, the teaching staff in the horticulture section of Ambo University College, for the follow up of the experiment during my absence. Thanks should also go to Ambo University College for financing this research. 
BALEMI, T.: Response of tomato cultivars differing in growth habit to nitrogen ...111

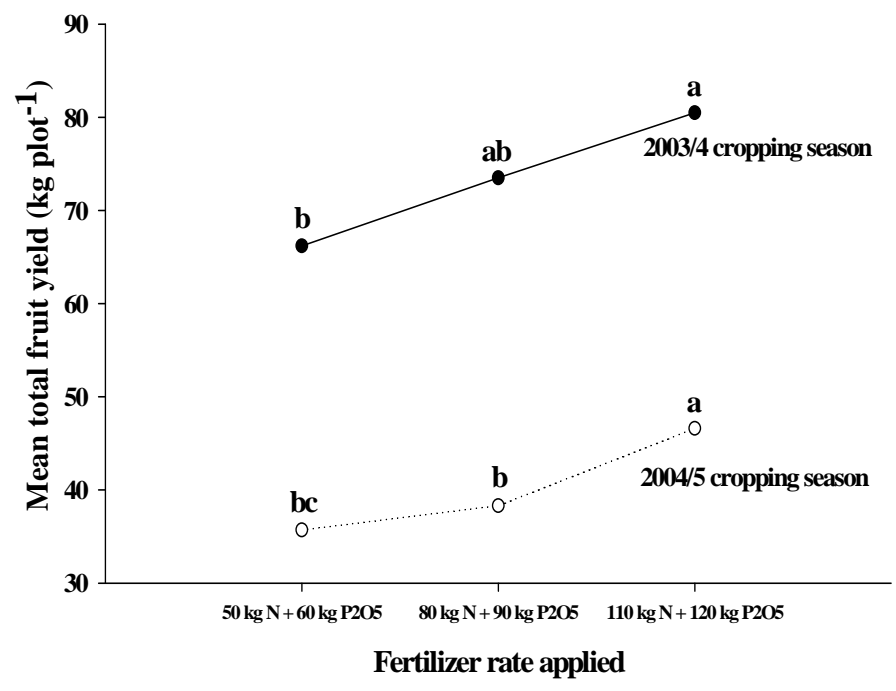

Figure 1. Total fruit yield of tomato cultivars as affected by fertilizer rate during both cropping seasons

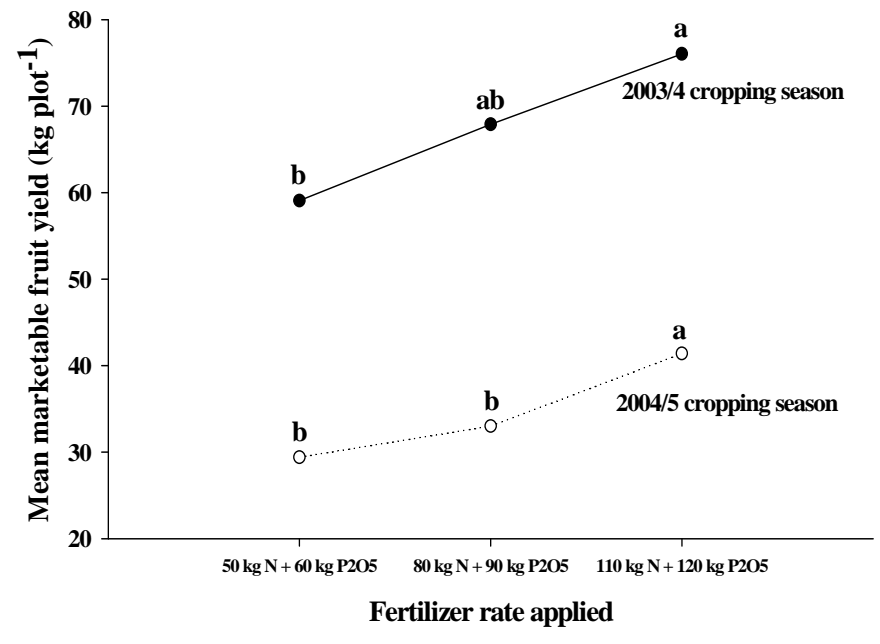

Figure 2. Marketable fruit yield of tomato cultivars as influenced by fertilizer rate during both cropping seasons 
112 Acta agriculturae Slovenica, 91 - 1, maj 2008

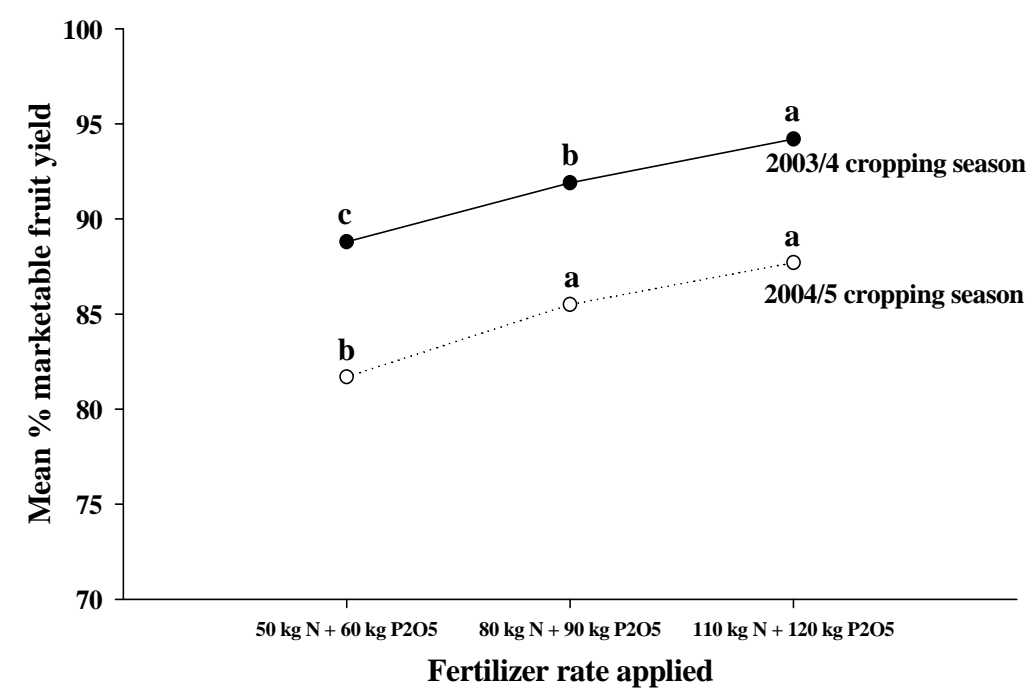

Figure 3. Percent marketable fruit yield of tomato cultivars as affected by fertilizer rate during both cropping seasons

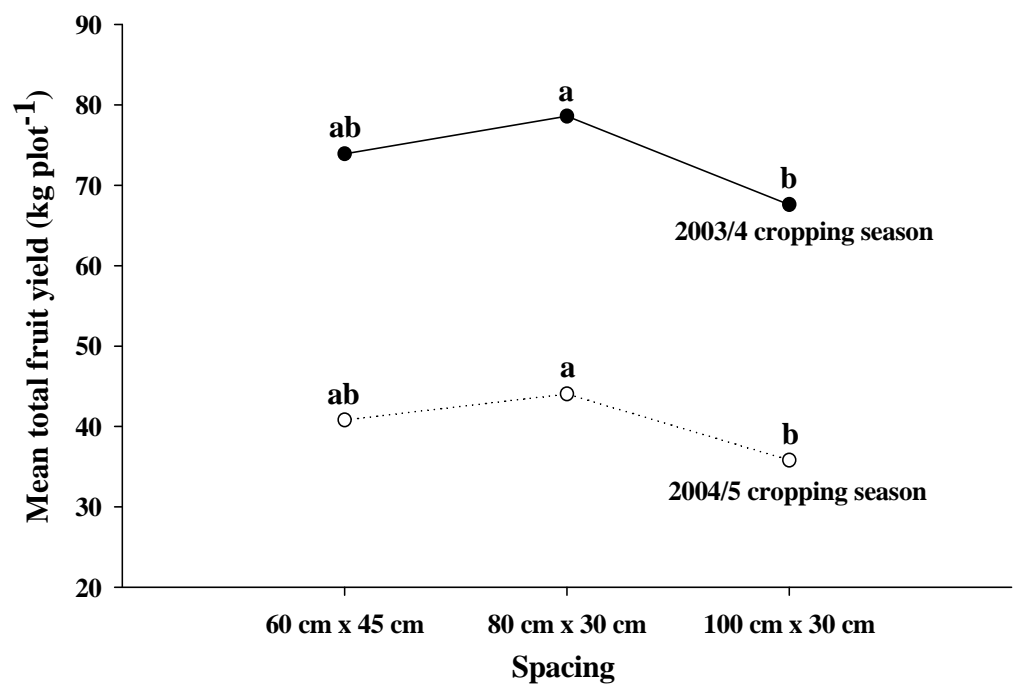

Figure 4. Total fruit yield of tomato cultivars as affected by spacing during both cropping seasons 
BALEMI, T.: Response of tomato cultivars differing in growth habit to nitrogen ...113

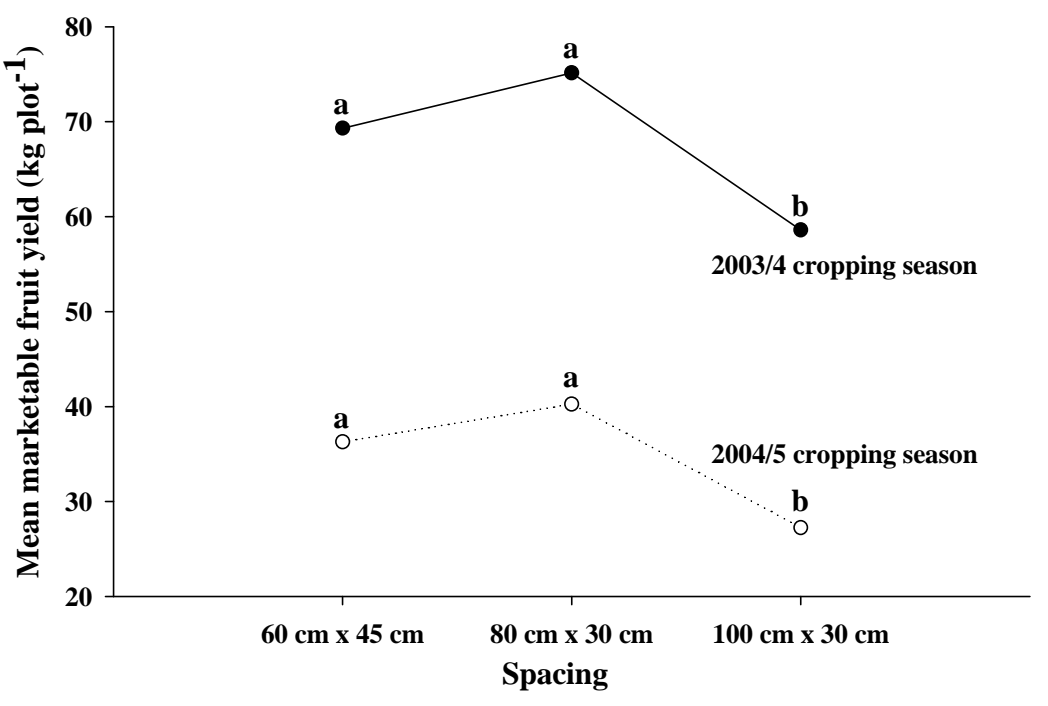

Figure 5. Marketable fruit yield of tomato cultivars as affected by spacing during both cropping seasons

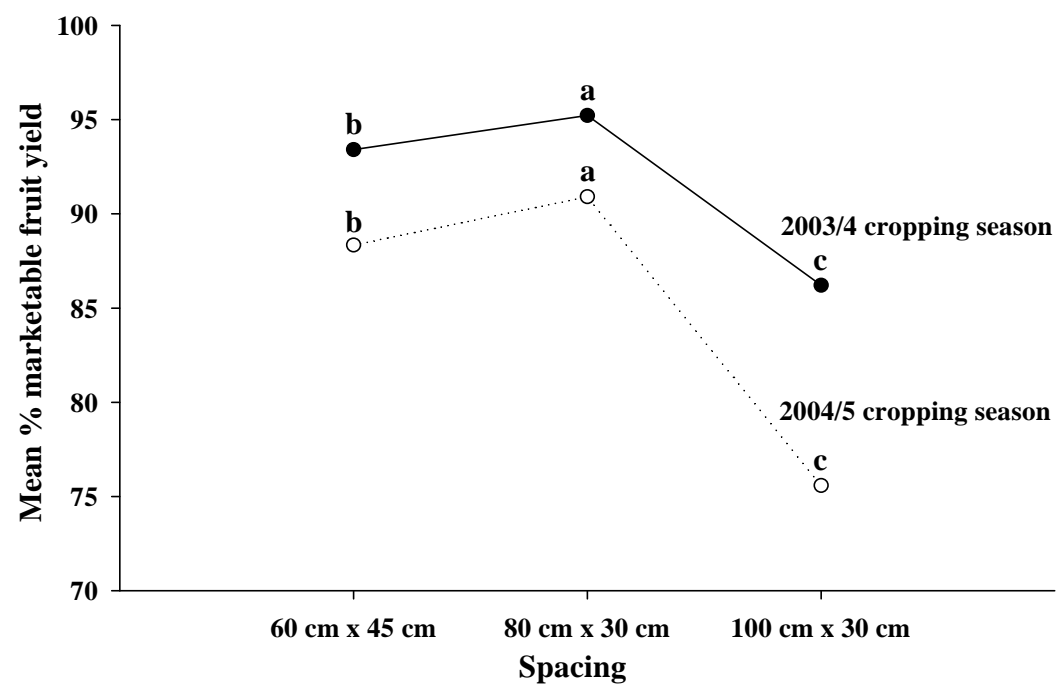

Figure 6. Percent marketable fruit yield of tomato cultivars as affected by spacing during both cropping seasons 


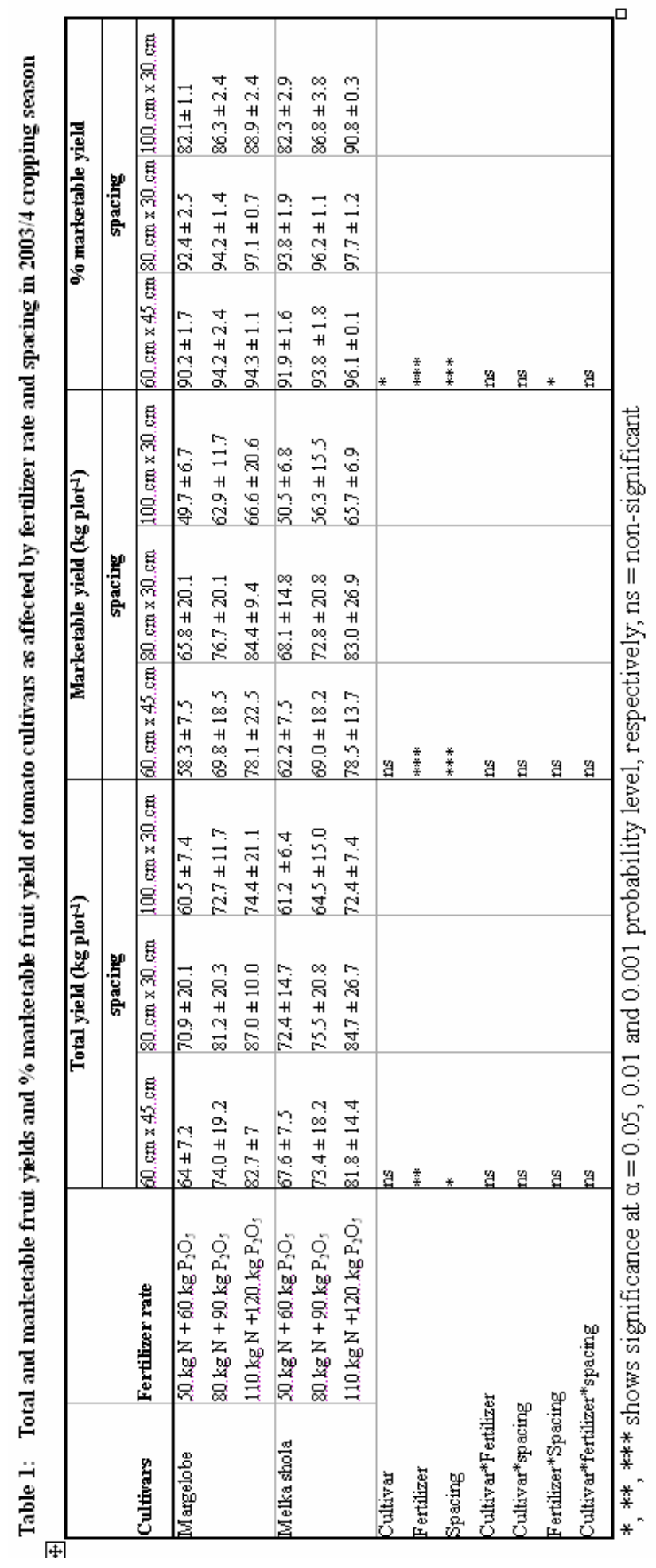


BALEMI, T.: Response of tomato cultivars differing in growth habit to nitrogen ...115

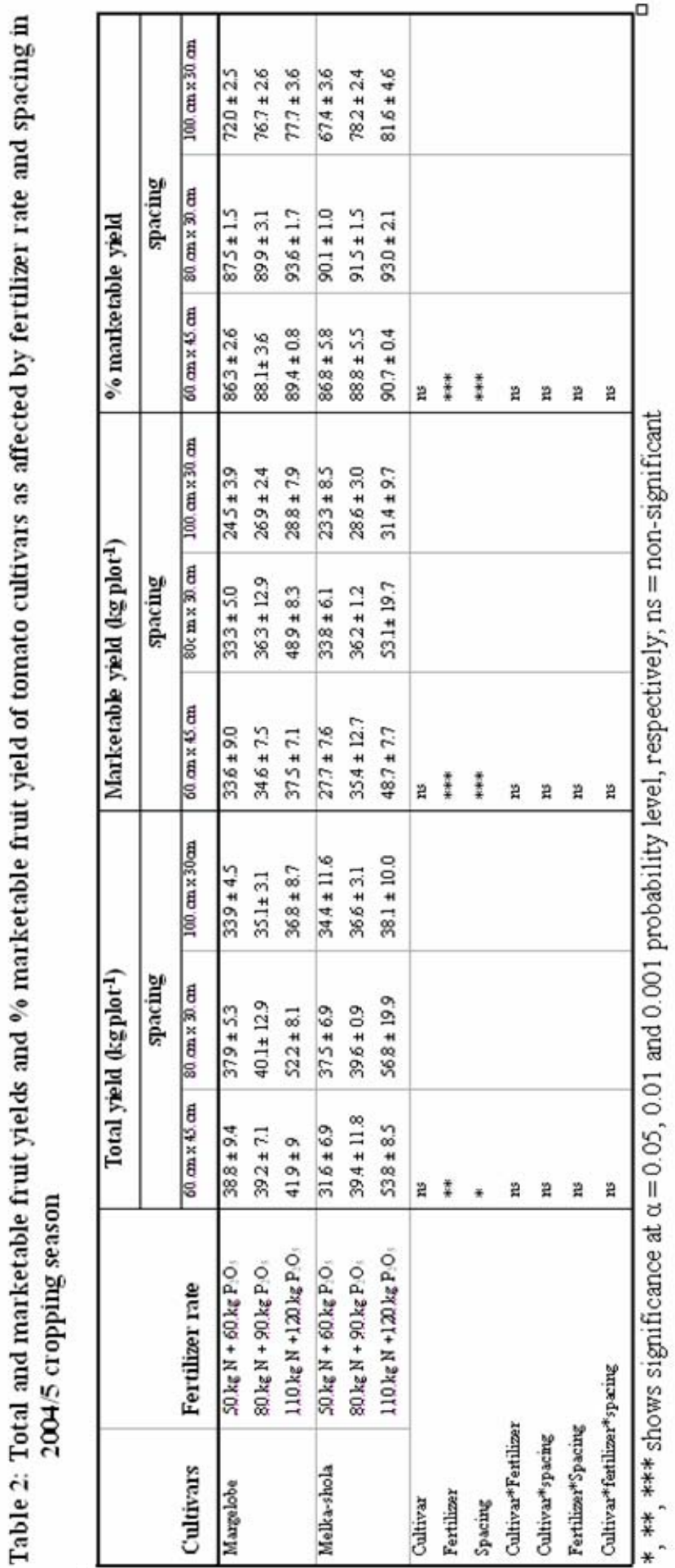




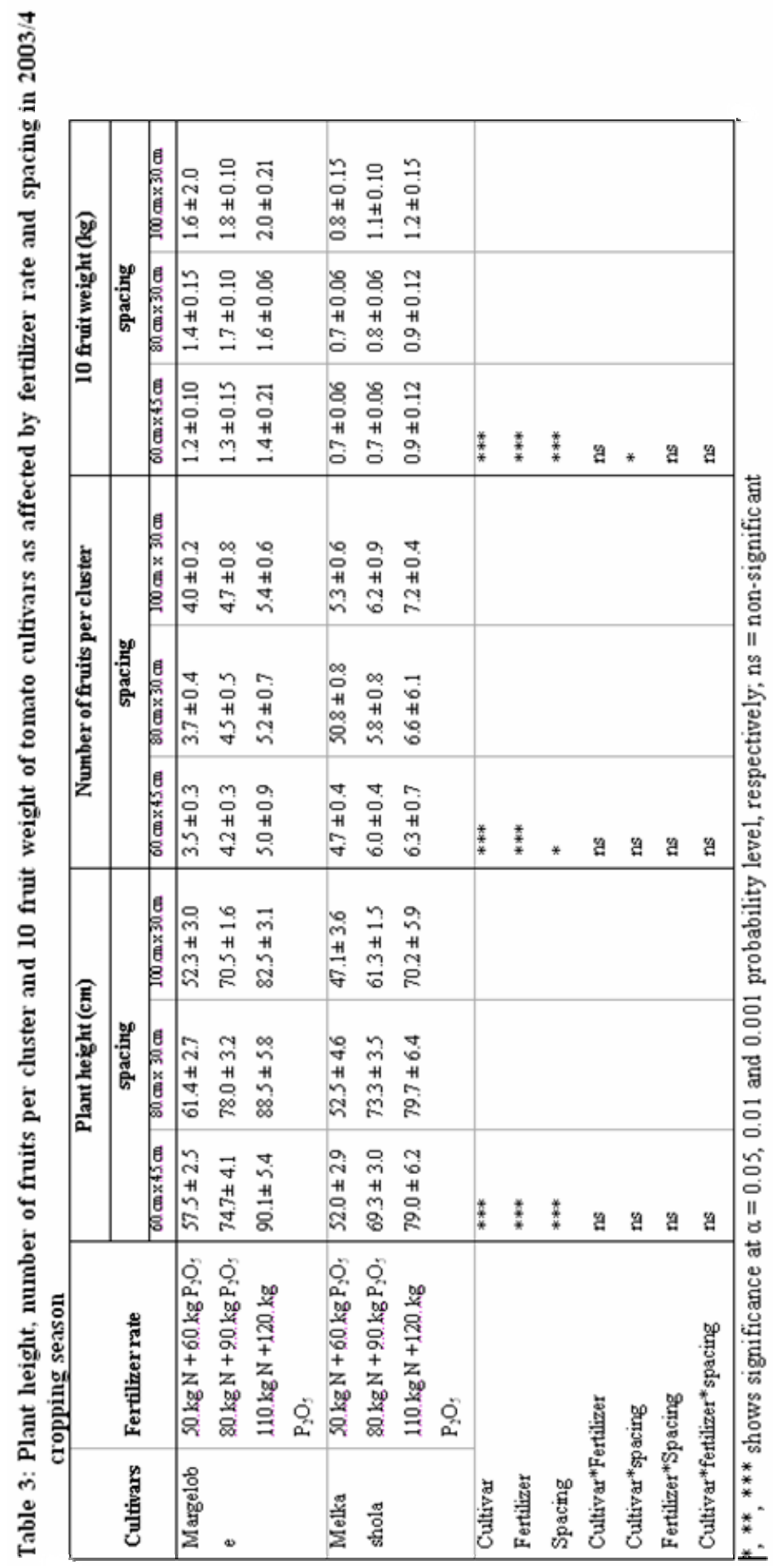


BALEMI, T.: Response of tomato cultivars differing in growth habit to nitrogen ...117

Table 4: Effect of main factors on plant height, number of fruits per cluster and 10 fruit weight of tomato cultivars

\begin{tabular}{llll}
\hline Main factors & $\begin{array}{l}\text { Mean plant } \\
\text { height }(\mathbf{c m})\end{array}$ & $\begin{array}{l}\text { Mean number of } \\
\text { fruits per cluster }\end{array}$ & $\begin{array}{c}\text { Mean 10 fruit } \\
\text { weight (kg) }\end{array}$ \\
\hline Cultivar & & & \\
Margelobe & $72.8^{\mathrm{a}}$ & $4.48^{\mathrm{b}}$ & $1.54^{\mathrm{a}}$ \\
Melka shola & $64.9^{\mathrm{b}}$ & $5.92^{\mathrm{a}}$ & $0.85^{\mathrm{b}}$ \\
LSD (5\%) & 2.34 & 0.35 & 0.07 \\
Fertilizer & & & \\
$50 \mathrm{~kg} \mathrm{~N}+60 \mathrm{~kg}$ & $53.8^{\mathrm{c}}$ & $4.39^{\mathrm{c}}$ & $1.23^{\mathrm{a}}$ \\
$\mathrm{P}_{2} \mathrm{O}_{5}$ & $71.2^{\mathrm{b}}$ & $5.24^{\mathrm{b}}$ & $1.31^{\mathrm{a}}$ \\
$80 \mathrm{~kg} \mathrm{~N}+90 \mathrm{~kg}$ & $81.7^{\mathrm{a}}$ & $5.97^{\mathrm{a}}$ & $1.05^{\mathrm{b}}$ \\
$\mathrm{P}_{2} \mathrm{O}_{5}$ & 3.46 & 0.51 & 0.11 \\
$110 \mathrm{~kg} \mathrm{~N}+120 \mathrm{~kg}$ & & & \\
$\mathrm{P}_{2} \mathrm{O}_{5}$ & $70.4^{\mathrm{a}}$ & $4.97^{\mathrm{b}}$ & $1.02^{\mathrm{c}}$ \\
LSD $(5 \%)$ & $72.2^{\mathrm{a}}$ & $5.16^{\mathrm{ab}}$ & $1.16^{\mathrm{b}}$ \\
Spacing & $64.0^{\mathrm{b}}$ & $5.48^{\mathrm{a}}$ & $1.41^{\mathrm{a}}$ \\
$60 \mathrm{~cm} \times 45 \mathrm{~cm}$ & 3.46 & 0.51 & 0.11 \\
$80 \mathrm{~cm} \times 30 \mathrm{~cm}$ & & & \\
$100 \mathrm{~cm} \times 30 \mathrm{~cm}$ & & & \\
LSD $(5 \%)$ & & & \\
\hline
\end{tabular}

Means for each main factor in the same column followed by the same letter are not significantly different from each other at $(\alpha=0.05)$ according to Tukey test

Table 5: Interaction effect of fertilizer rate and spacing on \% marketable fruit yield of the tomato cultivars

\begin{tabular}{|c|c|c|}
\hline Fertilizer rate & Spacing & \% Marketable fruit yield \\
\hline \multirow{4}{*}{$50 \mathrm{~kg} \mathrm{~N}+60 \mathrm{~kg} \mathrm{P}_{2} \mathrm{O}_{5}$} & $60 \mathrm{~cm} \times 45 \mathrm{~cm}$ & $91.1^{\mathrm{a}}$ \\
\hline & $80 \mathrm{~cm} \times 30 \mathrm{~cm}$ & $93.1^{\mathrm{a}}$ \\
\hline & $100 \mathrm{~cm} \mathrm{x} 30 \mathrm{~cm}$ & $82.2^{\mathrm{b}}$ \\
\hline & LSD (5 \%) & 2.3 \\
\hline \multirow[t]{4}{*}{$80 \mathrm{~kg} \mathrm{~N}+90 \mathrm{~kg} \mathrm{P}_{2} \mathrm{O}_{5}$} & $60 \mathrm{~cm} \mathrm{x} 45 \mathrm{~cm}$ & $94.0^{\mathrm{a}}$ \\
\hline & $80 \mathrm{~cm} \times 30 \mathrm{~cm}$ & $95.2^{\mathrm{a}}$ \\
\hline & $100 \mathrm{~cm} \times 30 \mathrm{~cm}$ & $86.6^{\mathrm{b}}$ \\
\hline & LSD (5 \%) & 2.2 \\
\hline \multirow[t]{4}{*}{$110 \mathrm{~kg} \mathrm{~N}+120 \mathrm{~kg} \mathrm{P}_{2} \mathrm{O}_{5}$} & $60 \mathrm{~cm} \times 45 \mathrm{~cm}$ & $95.2^{\mathrm{b}}$ \\
\hline & $80 \mathrm{~cm} \times 30 \mathrm{~cm}$ & $97.4^{\mathrm{a}}$ \\
\hline & $100 \mathrm{~cm} \mathrm{x} 30 \mathrm{~cm}$ & $89.9^{c}$ \\
\hline & LSD (5 \%) & 2.1 \\
\hline
\end{tabular}

Means for each fertilizer rate in a column followed by the same letter are not significantly different from each other at $(\alpha=0.05)$ according to Tukey test 
Table 6: Interaction effect of cultivar and spacing on mean value of 10 fruit weight

\begin{tabular}{|c|c|c|}
\hline Cultivar & Spacing & 10 fruit weight (kg) \\
\hline \multirow[t]{4}{*}{ Marglobe } & $60 \mathrm{~cm} \times 45 \mathrm{~cm}$ & $1.3^{\mathrm{c}}$ \\
\hline & $80 \mathrm{~cm} \mathrm{x} 30 \mathrm{~cm}$ & $1.5^{\mathrm{b}}$ \\
\hline & $100 \mathrm{~cm} \times 30 \mathrm{~cm}$ & $1.8^{\mathrm{a}}$ \\
\hline & LSD (5 \%) & 0.19 \\
\hline \multicolumn{3}{|c|}{ Melka shola } \\
\hline & $60 \mathrm{~cm} \times 45 \mathrm{~cm}$ & $0.76^{\mathrm{b}}$ \\
\hline & $80 \mathrm{~cm} \mathrm{x} 30 \mathrm{~cm}$ & $0.77^{\mathrm{b}}$ \\
\hline & $100 \mathrm{~cm} \times 30 \mathrm{~cm}$ & $1.03^{\mathrm{a}}$ \\
\hline & LSD (5 \%) & 0.13 \\
\hline
\end{tabular}

\section{REFERENCES}

Ali, S.M.R. 1995. Effect of Plant Population Density on Tomato. ARC Training Report. pp 13.

FAO. 2004. Production year book.

Godfrey-Sam-Aggrey, W. Turuwork A. and Tadelle A. 1985. Review of Tomato Research in Ethiopia and Proposal for future Research and Development direction. In: Godfrey-Sam-Aggrey and Bereke Tsehi (eds.). Proceedings of the First Ethiopian Horticultural Workshop. pp236-249.

Gupta, A. and Shukla, V. 1977. Response of tomato to plant spacing, nitrogen, phosphorus and potassium fertilizer. Indian J. Hort.34 (3): 270-276.

Hamid, M. 1985. Effect of Plant Density on Tomato Yield. ARC Training Report. pp 1-3. http://www.avrdc.org/LC/tomato/practices.html. January, 2007.

Jia, L. W. 1992. Plant Density Effect on Different Types of Tomato. ARC Training Report. pp 1-5.

Lemma, D., Yayeh, Z. and Herath, E. 1992. Agronomic Studies in Tomato and Capsicum. In: Herath and Lemma (eds.). Horticulture Research and Development in Ethiopia: Proceedings of the Second National Horticultural Workshops of Ethiopia. 1-3 December. Addis Ababa, Ethiopia. pp 153-163.

Mbinga, E.W. 1983. Pruning and Spacing Effect on Tomato var. Seeda Nam Khem. ARC Training Report. pp1-4.

Mehla, C.P., Srivastava, V.K., Jage, S., Mangat, R., Singh, J. and Ram, M. 2000. Response of tomato varities to $\mathrm{N}$ and $\mathrm{P}$ fertilization and spacing. Indian Jornal of Agricultural Research. 34 (3): 182-184.

Mohamed, S.F and Ali, Z.E. 1986. Effect of in-row Plant Spacing and Levels of Nitrogen Fertilizer on Yield and Quality of Direct-Seeded Tomatoes. Abstract. Symposium on Tomato Production on Arid Land. Acta Horticulturae 190 (1).

Nassar, H.H. 1986. Effect of Planting Pattern, Planting population and Nitrogen level on Yield and quality of Tomato. Abstract. Symposium on Tomato Production on Arid Land. Acta Horticulturae 190 (1). 
BALEMI, T.: Response of tomato cultivars differing in growth habit to nitrogen ...119

Pandey, R.P, Solanki, P.N, Saraf R.K and Parihar, M.S. 1996. Effect of Nitrogen and Phosphorus on growth and yield of tomato varieties. Punjab Vegetable Grower. 31: 1-5.

Rashid, M.D.A. 1993. Effect of Fertilizer Rates and Time of Application on Yield of Tomato. ARC Training Report. pp 1-3.

Reeve, E and Schmidth, W.A. 1952. Influence of plant spacing on canning tomato yields. Proc. Amer. Soc. Hort. Sci. 59: 384-388.

Sharma, K.C., Singh, A.K. and Sharma, S.K. 1999. Studies on Nitrogen and Phosphorus requirement of tomato hybrids. Annals of Agricultural Research. 20 (4): 339-402.

Teerapolvichitra, P. 1983. Effect of Plant Population Density on Tomato. ARC Training Report. pp 1-4.

Warner, H. 2003. Plant Spacing and Row Arrangement Affects Processing Tomato Yield. Agriculture and Agri-Food Canada. Ministry of Agriculture, Food and Rural Affairs.

Zahara, M. 1970. Influence of plant density on yield of processing tomatoes for mechanical harvest. J. Amer. Soc. Hort. Sci.94 (4): 510-512. 